Pak. j. sci. ind. res. Ser. A: phy. sci. 2021 64A(2) 173-190

\title{
Review
}

\section{Bisphenol A and its Analogues: Human Exposure and Biological Effects-A Review}

\author{
Ayesha Riaz ${ }^{\text {ab*}}$, Imran Pasha ${ }^{a}$, Mian Kamran Sharif and Sadaf Javaria ${ }^{\text {b }}$ \\ ${ }^{a}$ National Institute of Food Science and Technology, University of Agriculture, Faisalabad-38040, Pakistan \\ ${ }^{b}$ Institute of Food Science and Nutrition, Gomal University, D.I. Khan-29050, Pakistan
}

(received November 7, 2018; revised July 24, 2020; accepted September 18, 2020)

\begin{abstract}
The most prevalent exposure of bisphenol A (BPA) to biological systems has directed health organizations to reduce its safe dosage and the stringent regulation by developed countries that led to ban of BPA-based (Bisphenol analogues) baby bottles. This in turn has opened a new window for ongoing entry of bisphenol analogues into consumer market. Recently, there has been tremendous growth in both production and application of bisphenol analogues to achieve the "BPA-free" claim. Nevertheless, due to growing epidemiological evidence concerning the toxicological effects of these bisphenol analogues in both in vivo and in vitro systems, the debate regarding the safety concerns over bisphenols is back. Structural analogues of bisphenol A had been identified in food products, human and environment matrices. Present review is an attempt to recapitulate the presence of bisphenols in food and environment matrices as well as their concerning physiological effects in animal models and human groups. But, due to structural analogy of these substitutes, their endpoints on biological functions are comparable to original compound or in certain situations, more harmful than original compound. Unfortunately, other potentially harmful alternatives are emerging and it is therefore advised that the replacement of bisphenol A with other structural analogues must be executed with great care.
\end{abstract}

Keywords: bisphenol analogues, toxicity, food, environment, animal studies, human groups

\section{Introduction}

Bisphenol A, a man-made plastic monomer, virtually present everywhere in industrial world and human exposure to this compound is mainly through dietary and non-dietary sources. Epidemiological studies have evinced that major cause of neuro-behavioural diseases might be due to human exposure to endocrine disrupting chemicals such as bisphenol A (Ikhlas and Ahmad, 2020).

In recent years, scientific knowledge and public awareness has been increased concerning the negative endpoints of BPA (Vandenberg et al., 2013; Chapin et al., 2008). Owing to endocrine disrupting and putative obesogenic endpoints of BPA, the use of its analogues is growing (Zhu et al., 2020). Furthermore, consumer requirement for "bisphenol A-free" products resulted in substitution of BPA with other related chemicals as stated previously by Vandenberg et al. (2017) and Mathew et al. (2014). In this regard, BPS (4hydroxyphenyl sulfone), BPF (4,4'-methylene diphenol)

*Author for correspondence;

E-mail: ayeshahahaq06@yahoo.com and BPAF (4,4' hexafluoro isopropylidene) diphenol) are major alternatives of BPA in manufacturing polycarbonate (PC) plastics as well as epoxy resins (Dietrich et al., 2017; Liu et al., 2017) and bisphenol AF (BPAF).

On the other side, the safety of these potential alternatives regarding the induction of endocrine disrupting activity in human and animals is not ascertained absolutely (Rosenfeld, 2017). Their potential endpoints by genetic and non-genetic ways may have fostered the substitution of BPA with bisphenol analogues, which unfortunately have the same ill-effects. Several analogues and their derivatives have already been reported in human and environment and there is a growing concern over low dose and matrix related effects of these compounds (Caballero-Casero et al., 2016).

Among these, BPB, BPF, BPS and other analogues have been recognized as emerging contaminants in food, beverages (Cunha and Fernandes, 2013; Liao and Kannan, 2013; Gallart-Ayala et al., 2011), environmental media (Yang et al., $2014 \mathrm{a}, \mathrm{b}$ ) and biological samples (Zhou et al., 2014). Many studies have reported the 
occurrence of BPS and BPF in several personal care products and paper products (Liao and Kannan, 2014 a,b; Liao and Kannan, 2013; Liao et al., 2012 a). Strikingly, occurrence of BPF in mustard also recognizes it as natural compound of food (Zoller et al., 2016). This overview is to shed light on studies reporting toxicological impact of BPA and its analogues in in vivo (animal studies) and human groups. Also, to draw the attention of regulatory agencies to confront the burgeoning use of BPA and its analogues in consumer products.

Applications of bisphenol analogues. Epoxy coatings are commonly used in food ctaontainers and in drinking water supplies, water pipes in home and other buildings. Main constituents of epoxy coatings are bisphenols like $\mathrm{BPF}, \mathrm{BPA}$ and their reactive polymers, bisphenol $\mathrm{F}$ diglycidyl ether (BFDGE) and bisphenol A diglycidyl ether (BADGE), respectively. Therefore, it could be possible that leachates from epoxies might be susceptible to chemical disinfection i.e., free chlorine and monochloramine. Earlier studies have suggested that BADGE may migrate into drinking water and undergo hydrolysis (Lane et al., $2015 \mathrm{a}$ and b). BPF is widely used as liners, lacquers, water course and food container coatings (Cabaton et al., 2009). Furthermore, the applications of BPAF as a cross-linker in optical fibers, fluoroelastomers and a standard monomer for polyesters (Konno et al., 2004), polyamides and polycarbonate copolymers have been reported earlier (Baradie and Shoichet, 2005).

Industrial applications of BPS has been recognized for electro plating solvent, phenolic resins (Clark, 2012) and products sold as "BPA-free paper". BPS in costumer products like can coatings, epoxy glues and food-contact paper products, is highly common these days (Mathew et al., 2014; Naderi et al., 2014). A number of dealers switched to its analogue BPS, hypothetically considering the later to be safer (Russo et al., 2017) hence, increasing production of BPS per annum (Rochester and Bolden, 2015). Since, BPS has considerably lower estrogenic effects, good stability against elevated temperature, it was deliberated a "safe BPA alternative" as reported previously (Kuruto-Niwa et al., 2005). Nevertheless, due to negative endpoints pertaining to exposure to bisphenol A as well as other BPs like BPS and BPF (Zhou et al., 2014), are also under scrutiny by different world health organizations.
Biological effects of bisphenol analogues. From viewpoint of reproductive toxicology, the replacement of BPA, an extensively used constituent of plastic and non-plastic materials, with its analogues like BPS seems most important challenge (Žalmanova et al., 2016). Several publications based on in vitro studies delved into strong estrogenic (Rosenmai et al., 2014; Teng et al., 2013) and anti-androgenic effects (Eladak et al., 2015; Molina-Molina et al., 2013). On the basis of in vitro, many researchers (Feng et al., 2016; Peyre et al., 2014; Salvesen and Walsh, 2014; Fic et al., 2013; Lee et al., 2013) have showed that BPA may be cytotoxic and elicit DNA damage. It has been established that either BPA induced or was associated with ovary disorders in laboratory animals and human epidemiological studies (Peretz et al., 2014).

Earlier studies indicated estrogen effect of BPS in rats (Owens and Ashby, 2002) through a postnatal exposure both at low and high dosage levels (Yamasaki et al., 2004). Likewise, investigation by Vinas and Watson (2013a) and (2013b) established equal or greater estrogen efficacy compared to estradiol, BPS possessed the ability to stimulate the membrane receptor pathways usually up-regulated by estradiol. However, an in vitro study conducted by Rochester and Bolden (2015) pointed out a weak estrogen effect of BPS than activity established by estradiol. Therefore, regulation of BPF is uncertain due to its chronic intake by majority of people (Dietrich and Hengstler, 2016). Recently, Andújar et al. (2019) and Pelch et al. (2019) have reviewed the health consequences of BPA analogues particularly related to obesity and other physiological effects.

Animal studies. The effect of BPA and its derived compounds (3-hydroxybisphenol A and bisphenol A 3, 4-quinone) was examined on rat performance. It was noticed that only one intracisternal administration of BPA into Wistar male rats (5-day-old) elicited considerable hyperactivity in rats (4-5 weight), which was almost 1.3 times active during nocturnal stage compared to control. Conversely, its metabolites at similar quantity $(87 \mathrm{nmol})$ did not increase the motor activity. The analysis of treated brain through GC-MS have shown that $7 \%$ of parent compound resided in brain at 2 months however, its metabolites were not observed (Ishido et al., 2011). In research work of Abedelhaffez et al. (2017), the exposure of BPA was investigated on lung tissues of male rats. It was reported 
that chronic exposure might contribute in pulmonary inflammatory maladies with likely the initiation of lung fibrosis. The compendium of various studies reporting physiological effects in vivo of bisphenol analogues have been described in Table 1 .

It has been reported earlier that BPS exposure was found to elicit acute toxicity in Daphnia magna while, postnatal exposure led to uterine development in rats representing negative health effects of BPS in vivo (Yamasaki et al., 2004; Chen et al., 2002). Singh et al. (2016) studied the effect of BPA on male reproduction in Kadaknath chicken through oral BPA doses i.e., 1 or $5 \mathrm{mg} / \mathrm{Kg}$ body weight for a period of 7 weeks. The birds with BPA exposure ( $1 \mathrm{mg} / \mathrm{Kg}$ body weight) had highest semen volume than other groups while, the birds with BPA exposure ( $5 \mathrm{mg} / \mathrm{Kg}$ body weight) most considerably reduced sperm concentration compared to other treatment and control. The study outcomes show that bisphenol A indicated adverse effect on characteristics of sperm in chicken without impacting fertilization potential.

Past authors (Qiu et al., 2016, 2015; Kinch et al., 2015; Ji et al., 2013) substantiated the hypothesis that this compound may disrupt both reproduction and developmental effects in zebrafish thru endocrine ways. It has also been evinced that exposure to BPS may affect body weight as well as neuro behaviors in male offspring exposed developmentally (Kim et al., 2015). Published data have established the developmental toxicity of BPA in a range of models. Recently, the developmental toxicity of BPA has been evaluated during three developmental stages of zebrafish and findings showed that BPA exposure reduced reproductive development though, most significant changes were reported in treatment group having lowest concentration. Genetic effects on gamete development might be the cause of secondary effects of decreased fertilization, embryonic mortality and abnormalities (Chen et al., 2017).

In another study, fish (Labeo rohita) were administered to a sublethal BPA concentration of $0.73 \mathrm{mg} / \mathrm{L}$ for 35 days and hemato-biochemical and enzyme assays were done at the end of each week. The median lethal BPA concentration for $L$. rohita was assessed to be $7.3 \mathrm{mg} / \mathrm{L}$ for $24 \mathrm{~h}$. The data evinced a significant $(\mathrm{P}<0.05)$ reduction in hematological and biochemical factors in
BPA treated L. rohita than control groups (Krishnapriya et al., 2017). In a research work of Little and Seebacher (2015), they speculated that BPA toxicity could differ with environment temperature. For the purpose, zebrafish (Daniorerio) was exposed to an environmentally related and artificially higher BPA concentrations at two acclimation temperature. They reported that the environmentally relevant level of BPA $(20 \mu \mathrm{g} / \mathrm{L})$ impaired swimming activity, heart rate and gene expression.

Faheem et al. (2017) probed the impact of BPA exposure $(10,100$ and $1000 \mu \mathrm{g} / \mathrm{L})$ on thyroid and steroid hormone levels of a cyprinid (Catla catla). They found that plasma estradiol considerably augmented as a result of BPA exposure (@100 and 1000 mg/L).After two weeks, a substantial reduction in plasma testosterone, triiodothyroxin and thyroxin was documented. Moreover, plasma FSH levels displayed a significant escalation only at BPA exposure of $10 \mu \mathrm{g} / \mathrm{L}$. BPA exposure at $1000 \mu \mathrm{g} / \mathrm{L}$ significantly increased the plasma luteinizing hormone in fish. Hence, the alteration in sex hormone as well as gonadotropin levels can elicit reproductive dysfunction.

Nevertheless, BPA and its halogenated derivatives $(\mathrm{H}-$ BPAs) have been identified in organisms and environment but, there is limited data regarding their toxicity, particularly chronic exposure at low doses. In this context, Huang et al. (2017) systematically evaluated and compared the impact of BPA and H-BPAs on reproduction and growth effects of Oryzias melastigma at various development stages.

Bisphenol $\mathrm{A}$ and its derived compounds such as tetrachlorobisphenol A (TCBPA) and tetrabromobisphenol A (TBBPA) were observed to escalate embryonic heartbeat. Also, BPA exposure slowed down oocyte development in ovary, decreased estrogen and testosterone levels rather than HBPAs. While, in male fish, insignificant change was noticed in testis. However, BPA had no substantial effect on hatch time whereas, TBBPA and TCBPA reduced hatching rate. Overall, TCBPA exhibited most toxic effect on hatching followed by TBBPA and BPA.

Human studies. Biomonitoring studies divulge that human BPS exposure is prevailing (Ye et al., 2015). Similar to BPA, human are exposed to BPS primarily by dermal absorption and ingestion from dust, can 


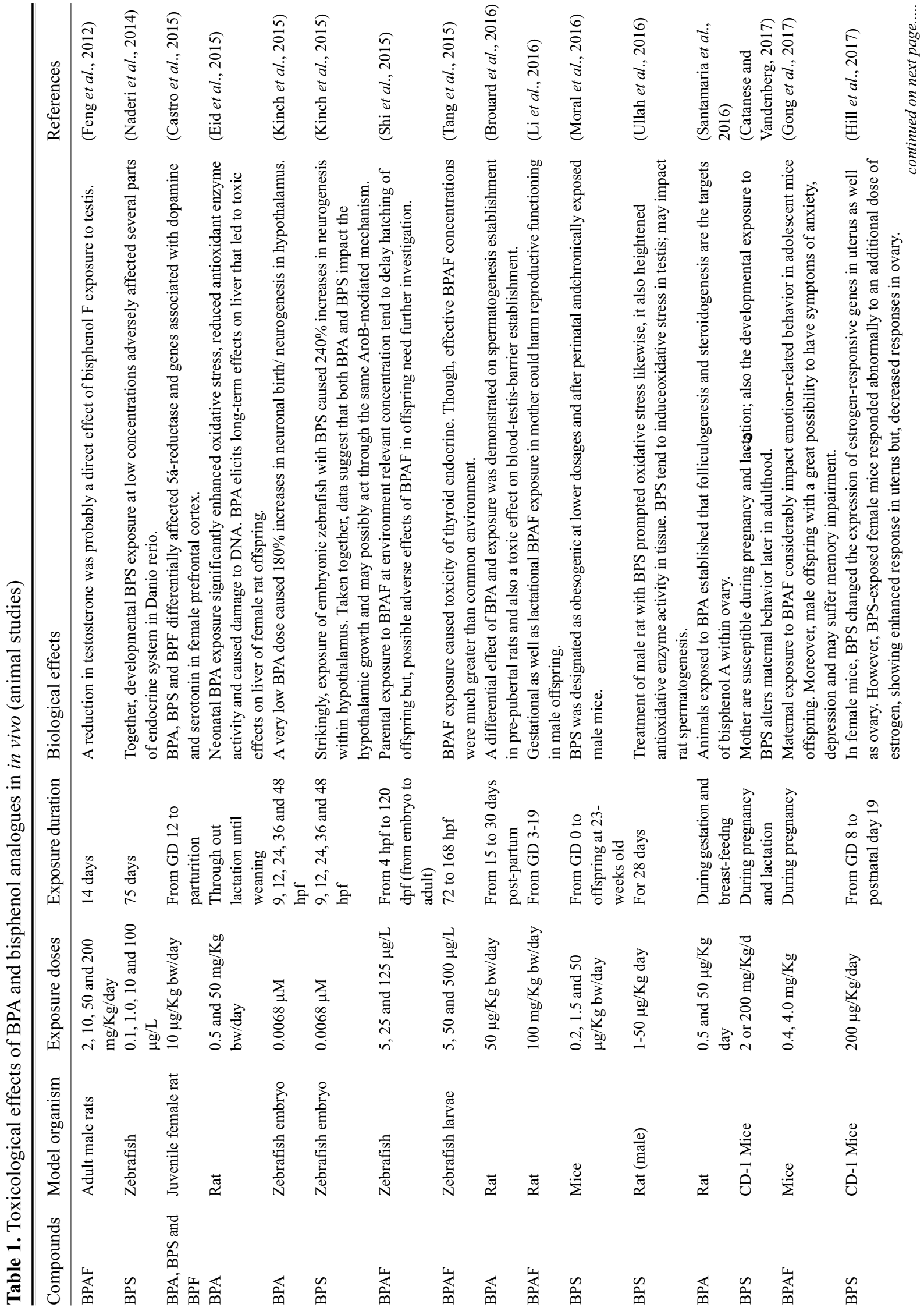


linings and plastic leachates (Porras et al., 2014). Among bisphenols, median concentrations in urine specimens of individuals in US were detected as 0.72 (BPA), followed by 0.13 (BPS) and $0.08 \mathrm{nsg} / \mathrm{mL}$ (BPF) (Zhou et al., 2014). Human studies entailing bisphenols (BPF and BPS along with BPA) in different studied groups and their consequences on human health are summarized in Table 2. Asimakopoulos et al. (2015) analyzed urine specimens in general population from Saudi Arabia and found the concentrations of bisphenol analogues as 13.3 (BPS), 4.92 (BPA), 0.30 (BPAP), 0.19 (BPF), 0.05 $\mathrm{ng} / \mathrm{mL}$ (BPB and BPAF).

A study comprising data from US and 7 Asian countries reported BPS in $81 \%$ of human urine samples (21 $\mathrm{ng} / \mathrm{mL}$ ) (Liao et al., 2012b). Highest BPS levels were detected in urine samples collected from Japan as 1.180 followed by 0.299 (US) and $0.226 \mathrm{ng} / \mathrm{mL}$ (China and other countries). A number of bisphenol analogues were reported in urine specimens from Chinese people living nearby a BPAF production plant as 0.886 (BPA), 0.018 (BPAF), 0.228 (BPF) and $0.029 \mathrm{ng} / \mathrm{mL}$ (BPS) (Yang et al., $2014 \mathrm{a}, \mathrm{b})$.

In India, BPS concentration in children resulted as 0.05 (obese) and 0.61 (non-obese) ng/mL (Xue et al., 2015). Moreover, BPS turn out to be most prominent analogue in urine specimens from people of Saudi Arabia with median concentration of 4.92 as compared to 2.01 (BPA) and $2.16 \mathrm{ng} / \mathrm{mL}$ (BPF) (Asimakopoulos et al., 2015). Another study by Cobellis et al. (2009) demonstrated the occurrence of BPB in human sera $(5.15 \mathrm{ng} / \mathrm{mL})$ from Italian female that was larger as compared to 2.91 $\mathrm{ng} / \mathrm{mL}$ (BPA).

As BPA is under regulations, human exposures to BPF and BPS is likely to increase therefore, bio-monitoring of bisphenol analogues is necessary. In this background, Zhou et al. (2014) detected bisphenol analogues and their median concentrations were observed as 0.72 (BPA), 0.13 (BPS) and $0.08 \mathrm{ng} / \mathrm{mL}$ (BPF). Peng et al. (2016) detected environmental estrogens including bisphenol A, nonylphenol and phthalate monoesters in urine samples of Chinese women (Nanjing area) with unexplained recurrent miscarriage. The average concentration of BPA in women with recurrent miscarriage was $7.13 \mathrm{ng} / \mathrm{mL}$ as compared to control group (4.43 ng/mL). On contrary, Yamamoto et al. (2016) found no relationship between BPA levels of maternal and fetal blood. During pregnancy, frequent 


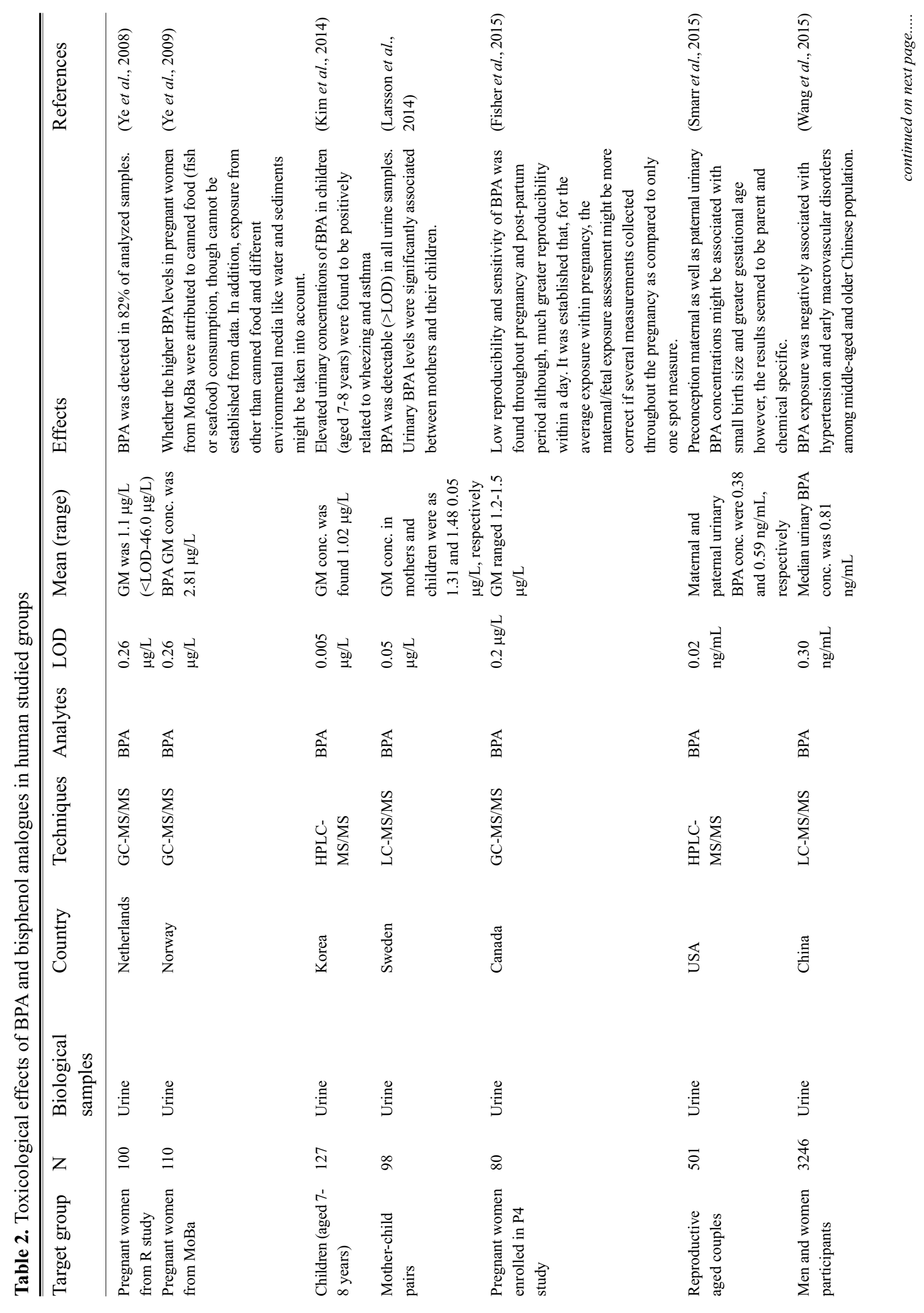




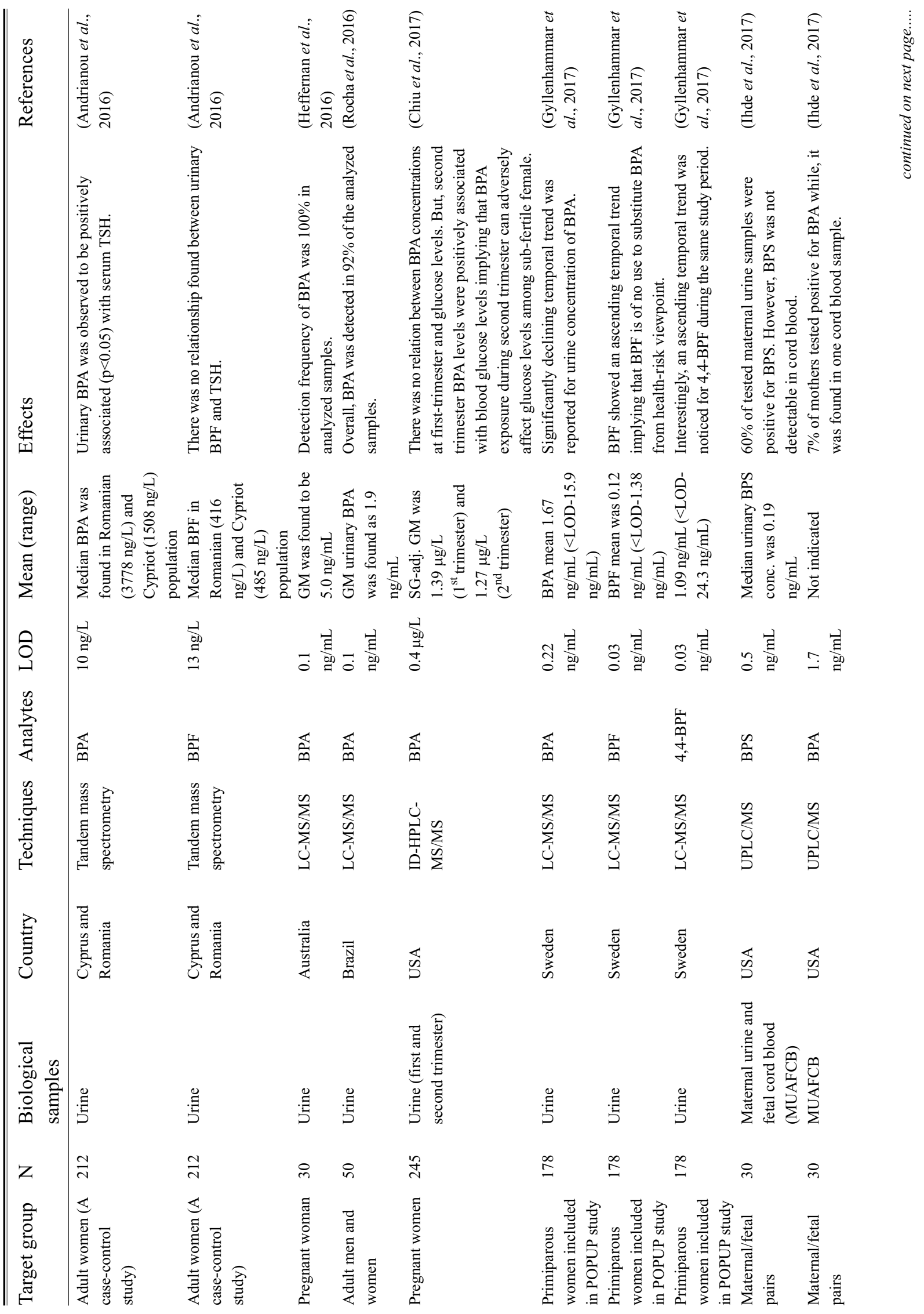




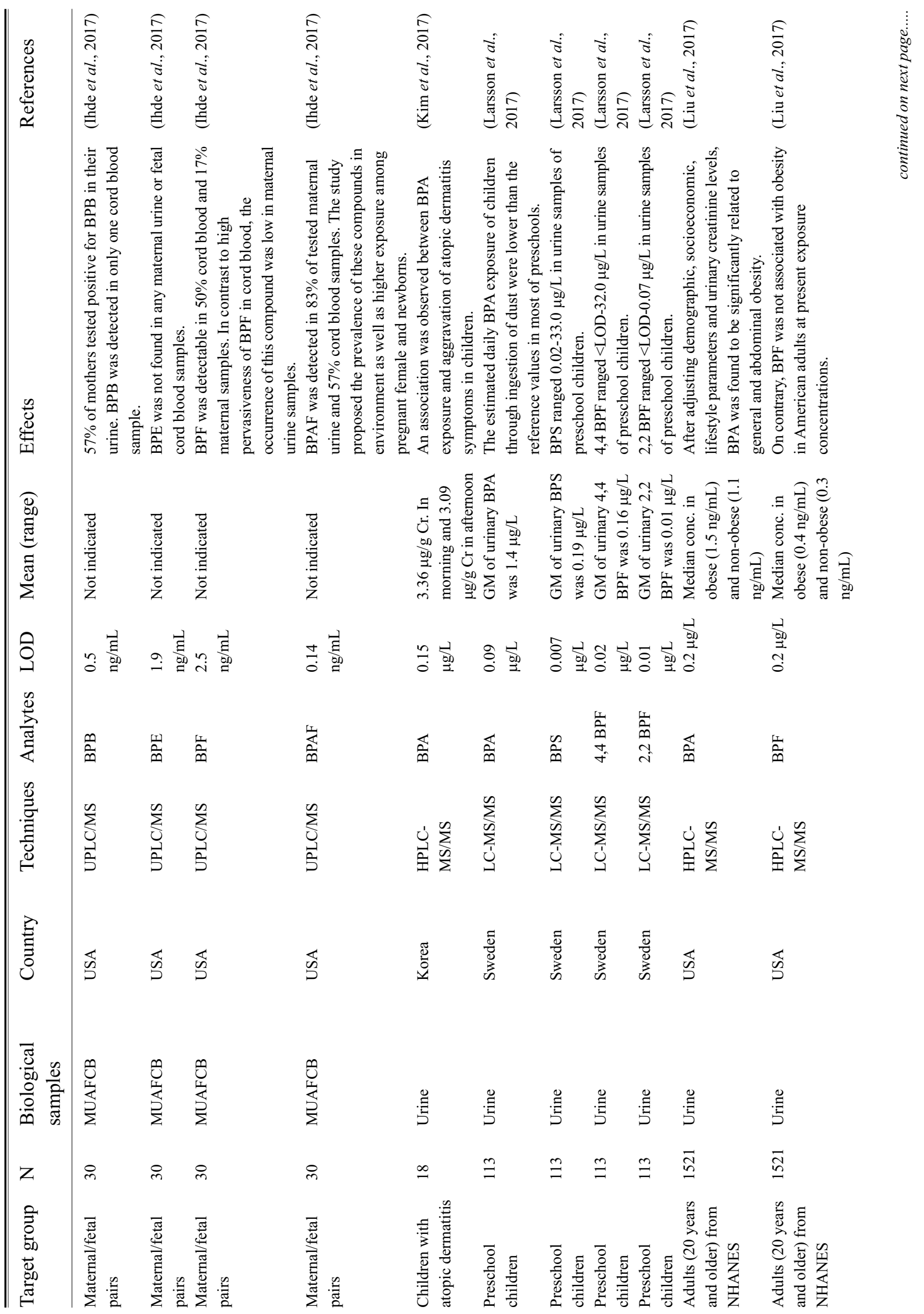




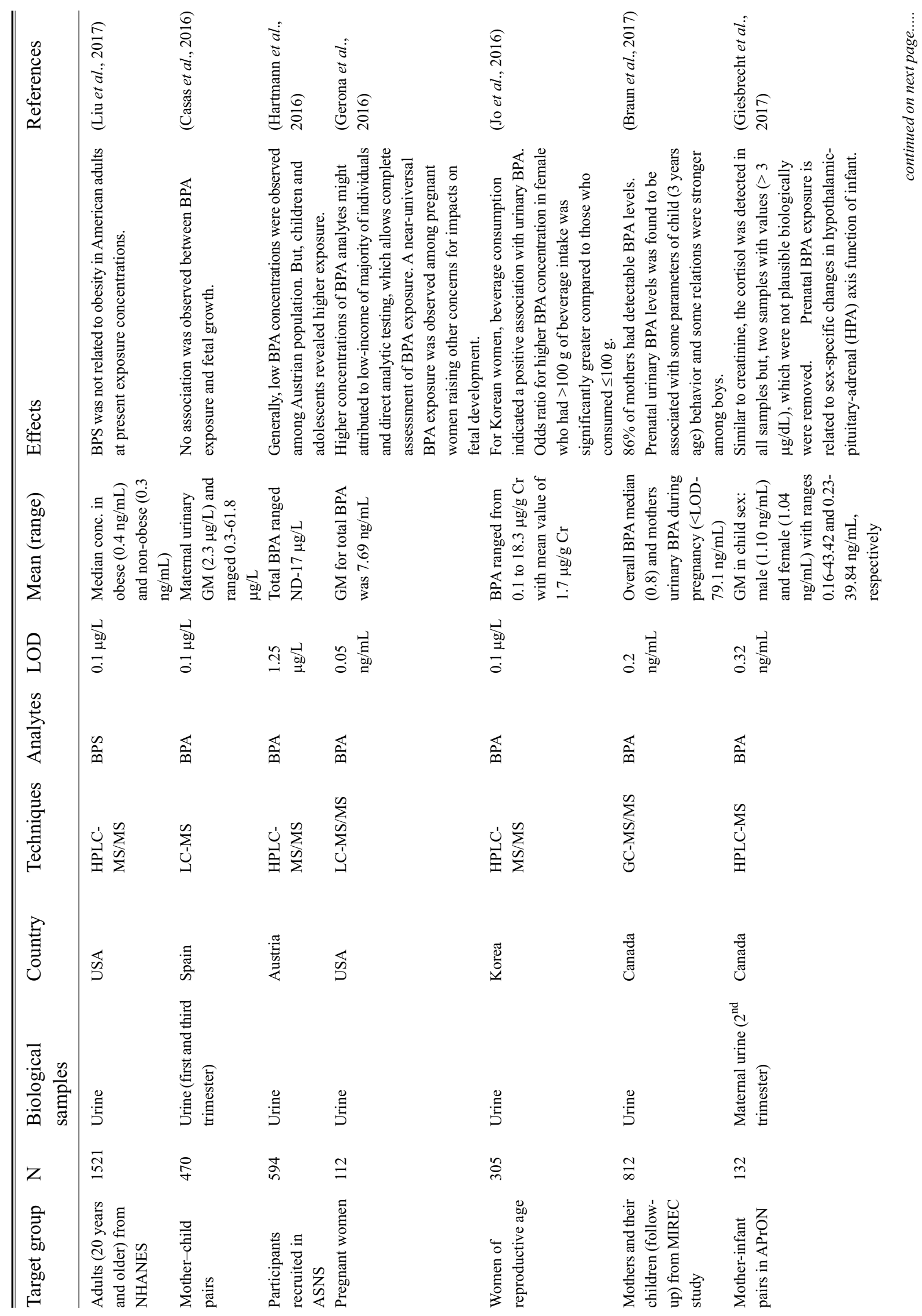




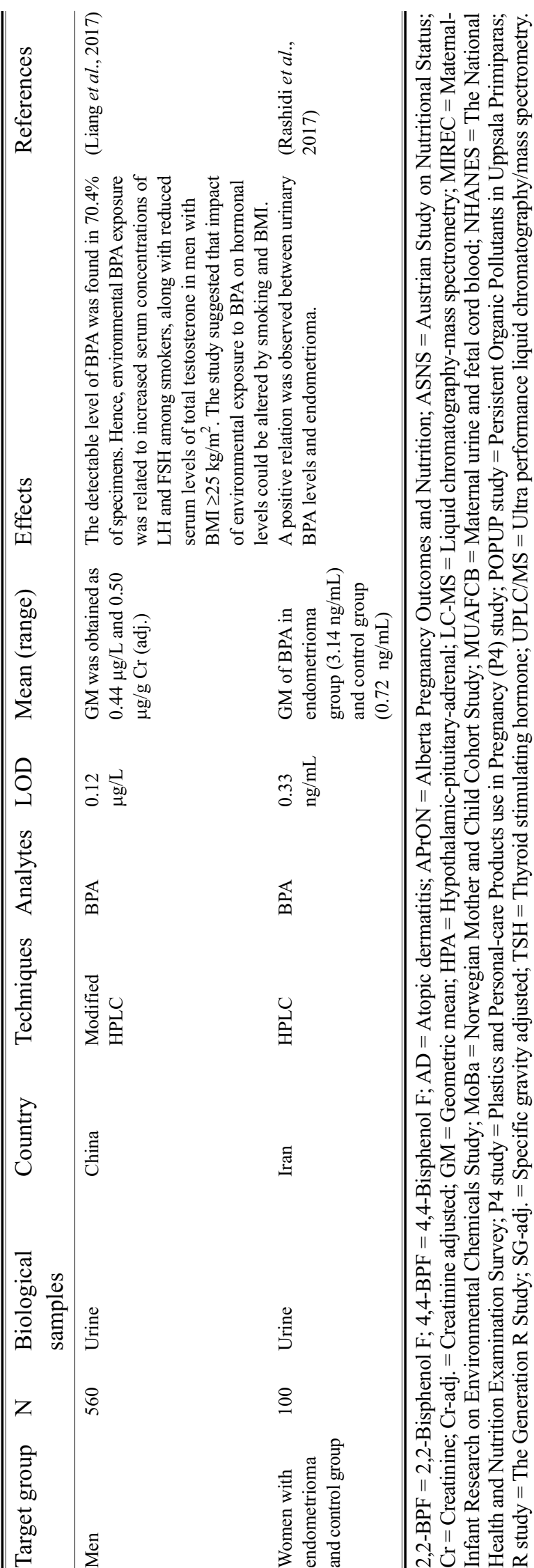

consumption of beef and pork was found to be positively correlated to maternal BPA concentrations. BPA level of maternal blood was determined as 0.419 whereas, in cord blood was found as $0.217 \mathrm{ng} / \mathrm{mL}$.

In United States, Liu et al. (2017) observed relationship between obesity and bisphenols exposure in 1521 participants and reported that obese adults had greater levels of BPA, BPS and BPF as compared to non-obese individuals. After adjusting demographic, socioeconomic parameters and urinary creatinine levels, neither BPF nor BPS, but only BPA was found to be significantly related to obesity (general and abdominal) in US adults at present exposure concentration. Also, odds ratios (ORs) for general obesity were found as BPA (1.78), BPF (1.02) and BPS (1.22). Pell et al. (2017) examined the association between the parental concern regarding the environmental chemical contacts and urinary phthalate and phenol levels in their school-age children (8 years) in Ohio. They reported that concentrations of 4 phthalates, BPA and BPS were lower in children whose parents $(\mathrm{n}=122)$ were more concerned about environmental chemicals than those $(n=96)$ who did not.

Owing to an increase volume of scientific studies and public knowledge regarding the adverse endpoints of BPA exposure, there is beginning to phase out BPA from numerous products. Previous studies have documented that being an endocrine disruptor, application of BPA has been inhibited in various products. As, several products are marketed with a "bisphenol A-free" guarantee due to its replacement with BPS however, these products are not "BPA-free", and their usage might be associated with considerable reproductive toxicity (Glausiusz, 2014).

Pakistan's perspective. On contrary, situation is even more worst in developing countries like Pakistan. BPA has not been recognized as a real concern at national level and there is limited data available that is however, based on scientific research. Due to insufficient scientific data regarding levels of BPA and its analogues in food matrices make the estimation of their dietary intake more problematic in Pakistan. In current scenario, production and marketing of bisphenols containing materials will tend to increase and so does health risks due to absence of regulation and governing bodies. In this milieu, a more systematic framework is required in Pakistan for regulating this ubiquitous chemical. It 
is the need of hour that bio-monitoring studies of bisphenols should be conducted at national level to evaluate the health-related risk of Pakistani population particularly, infant, children and pregnant women. Pakistan Environment Protection Agency and Provincial Food Authorities should develop policies and regulatory framework and take stern on bisphenol compounds in food packaging and other food contact materials.

On the other side, environmental experts and health professionals should organize community programmes for public awareness for health menace of bisphenols. Such approaches could also be effective to determine association between bisphenol exposure and occurrence of hormone-based disorders. Nonetheless, human exposure to bisphenols is inevitable, it could be reduced by adopting some steps. Food and beverages contained in cans are the major contributor for bisphenol A toxicity thus, consumption of canned food should be reduced. Polycarbonate plastic packaging can also release bisphenol A on heating and at recurrent use therefore, the practice to microwave food in polycarbonate material should be restricted.

\section{Conclusion}

Due to restriction on applications of bisphenol $\mathrm{A}$ in baby bottles and other packaging container, there has been an impetus to find safer BPA alternatives. Therefore, industry has switched from the removal of BPA towards the application of its substitutes. Published data reported negative endpoints of BPA analogues comparable or even higher than BPA. These contaminants are harmful to various organ and systems of human body including reproduction, thyroid and nervous system. Preferably, alternatives used in order to substitute a chemical must be inert, or less harmful as compared to original compound. Unfortunately, similar to BPA, its structural analogues have been under scrutiny due to their endocrine disrupting activities. Importantly, the use of bisphenol family of chemicals should be kept at minimum particularly for food contact materials. Moreover, the safety assessment of a certain chemical or chemical replacement should be carried out before it takes its way to market particularly, as substitutes for toxic compounds. There should be an adequate public awareness to encourage people particularly, children and adolescents to use packaging other than plastics such as glass, stainless steel, paper and ceramic.
Conflict of Interest. The authors declare no conflict of interest.

\section{References}

Abedelhaffez, A.S., Abd El-Aziz, E.A., Abdel Aziz, M.A., Ahmed, A.M. 2017. Lung injury induced by Bisphenol A: A food contaminant, is ameliorated by selenium supplementation. Pathophysiology, 24: 81-89.

Andrianou, X.D., GaÈngler, S., Piciu, A., Charisiadis, P., Zira, C., Aristidou, K., Piciu, D., Hauser, R., Makris, K.C. 2016. Human exposures to bisphenol $\mathrm{A}$, bisphenol $\mathrm{F}$ and chlorinated bisphenol $\mathrm{A}$ derivatives and thyroid function. PLOS ONE, 11: e0155237.

Andújar, N., Gálvez-Ontiveros, Y., Zafra-Gómez, A., Rodrigo, L., Álvarez-Cubero, M.J., Aguilera, M., Monteagudo, C., Rivas, A. 2019. Bisphenol A analogues in food and their hormonal and obesogenic effects: A review. Nutrients, 11: 2136.

Asimakopoulos, A.G., Xue, J., De Carvallo, B.P., Iyer, A., Abualnaja, K.O., Yaghmoor, S.S., Kumosani, T.A., Kannan, K. 2015. Urinary biomarkers of exposure to 57 xenobiotics and its association with oxidative stress in a population in Jeddah, Saudi Arabia. Environmental Research, 150: 573-581.

Baradie, B., Shoichet, M.S. 2005. Novel fluoroterpolymers for coatings applications. Macromolecules, 38: 5560-5568.

Braun, J.M., Muckle, G., Arbuckle, T., Bouchard, M.F., Fraser, W.D., Ouellet, E., Séguin, J.R., Oulhote, Y., Webster, G.M., Lanphear, B.P. 2017. Associations of prenatal urinary bisphenol A concentrations with child behaviors and cognitive abilities. Environmental Health Perspectives, 125: 067008.

Brouard, V., Guénon, I., Bouraima-Lelong, H., Delalande, C. 2016. Differential effects of bisphenol A and estradiol on rat spermatogenesis' establishment. Reproductive Toxicology, 63: 4961.

Caballero-Casero, N., Lunar, L., Rubio, S. 2016. Analytical methods for the determination of mixtures of bisphenols and derivatives in human and environmental exposure sources and biological 
fluids. A review. Analytica Chimica Acta, 908: 22-53.

Cabaton, N., Dumont, C., Severin, I., Perdu, E., Zalko, D., Cherkaoui-Malki, M., Chagnon, M.C. 2009. Genotoxic and endocrine activities of bis(hydroxyphenyl)methane (bisphenol F) and its derivatives in the $\mathrm{HepG}_{2}$ cell line. Toxicology, 255: 15-24.

Casas, M., Valvi, D., Ballesteros-Gomez, A., Gascon, M., Fernández, M.F., Garcia-Esteban, R., Iñiguez, C., Martínez, D., Murcia, M., Monfort, N., Luque, N., Rubio, S., Ventura, R., Sunyer, J., Vrijheid, M. 2016. Exposure to bisphenol A and phthalates during pregnancy and ultrasound measures of fetal growth in the INMA-Sabadell Cohort. Environmental Health Perspectives, 124: 521-528.

Castro, B., Sánchez, P., Torres, J.M., Ortega, E. 2015. Bisphenol A, bisphenol $\mathrm{F}$ and bisphenol $\mathrm{S}$ affect differently $5 \alpha$-reductase expression and dopamineserotonin systems in the prefrontal cortex of juvenile female rats. Environmental Research, 142: 281287.

Catanese, M.C., Vandenberg, L.N. 2017. Bisphenol S (BPS) alters maternal behaviour and brain in mice exposed during pregnancy/lactation and their daughters. Endocrinology, 158: 516-530.

Chapin, R.E., Adams, J., Boekelheide, K., Gray, L.E., Hayward, S.W., Lees, M.B.S., Portier, K.M., Schnorr, T.M., Selevan, S.G., Vandenbergh, J.G., Woskie, S.R. 2008. NTP-CERHR expert panel report on the reproductive and developmental toxicity of bisphenol A. Birth Defects Research Part B: Developmental and Reproductive Toxicology, 83: 157-395.

Chen, J., Saili, K.S., Liu, Y., Li, L., Zhao, Y., Jia, Y., Bai, C., Tanguay, R.L., Dong, Q., Huang, C. 2017. Developmental bisphenol A exposure impairs sperm function and reproduction in zebrafish. Chemosphere, 169: 262-270.

Chen, M., Ike, M., Fujita, M. 2002. Acute toxicity, mutagenicity and estrogenicity of bisphenol-A and other bisphenols. Environmental Toxicology, 17: 80-86.

Chiu, Y.-H., M'inguez-Alarco'n, L., Ford, J.B., Keller, M., Seely, E.W., Messerlian, C., Petrozza, J., Williams, P.L., Ye, X., Calafat, A.M., Hauser, R.,
James-Todd, T. 2017. Trimester-specific urinary bisphenol A concentrations and blood glucose levels among pregnant women from a fertility clinic. The Journal of Clinical Endocrinology and Metabolism, 102: 1350-1357.

Clark, E. 2012. Sulfolane and sulfones. In: Kirk-Othmer Encyclopedia of Chemical Technology. John Wiley \& Sons, New York, USA.

Cobellis, L., Colacurci, N., Trabucco, E., Carpentiero, C., Grumetto, L. 2009. Measurement of bisphenol A and bisphenol B levels in human blood sera from healthy and endometriotic women. Biomedical Chromatography, 23: 1186-1190.

Cunha, S.C., Fernandes, J.O. 2013. Assessment of bisphenol A and bisphenol B in canned vegetables and fruits by gas chromatography-mass spectrometry after QuEChERS and dispersive liquid-liquid micro extraction. Food Control, 33: 549-555.

Dietrich, D.R., Hengstler, J.G. 2016. From bisphenol A to bisphenol $\mathrm{F}$ and a ban of mustard due to chronic low dose exposures? Archives of Toxicology, 90: 489-491.

Dietrich, M., Franke, M., Stelter, M., Braeutigam, P. 2017. Degradation of endocrine disruptor bisphenol A by ultrasound assisted electrochemical oxidation in water. Ultrasonics Sonochemistry, 39: 741-749.

Eid, J.I., Eissa, S.M., El-Ghor, A.A. 2015. Bisphenol A induces oxidative stress and DNA damage in hepatic tissue of female rat offspring. The Journal of Basic and Applied Zoology, 71: 10-19.

Eladak, S., Grisin, T., Moison, D., Guerquin, M.-J., N'Tumba-Byn, T., Pozzi-Gaudin, S., Benachi, A., Livera, G., Rouiller-Fabre, V., Habert, R. 2015. A new chapter in the bisphenol A story: bisphenol $\mathrm{S}$ and bisphenol $\mathrm{F}$ are not safe alternatives to this compound. Fertility and Sterility, 103: 11-21.

Faheem, M., Khaliq, S., Ahmad, H.U., Lone, K.P. 2017. Bisphenol-A (BPA) alters plasma thyroid hormones and sex steroids in female Pakistani major carp (Catla catla; Cyprinidae). Pakistan Veterinary Journal, 37: 326-330.

Feng, Y., Yin, J., Jiao, Z., Shi, J., Li, M., Shao, B. 2012. Bisphenol AF may cause testosterone reduction by directly affecting testis function in adult male rats. Toxicology Letters, 211: 201-209. 
Feng, Y., Jiao, Z., Shi, J., Li, M., Guo, Q., Shao, B. 2016. Effect of bisphenol analogues on steroidogenic gene expression and hormone synthesis in H295R cells. Chemosphere, 147: 9-19.

Fic, A., Zegura, B., Dolenc, S.M., Filipic, M., Masic, P.L. 2013. Mutagenicity and DNA damage of bisphenol A and its structural analogues in $\mathrm{HepG}_{2}$ cells. Arhiv Za Higijenu Rada I Toksikologiju, 64: $189-200$.

Fisher, M., Arbuckle, T.E., Mallick, R., LeBlanc, A., Hauser, R., Feeley, M., Koniecki, D., Ramsay, T., Provencher, G., Bérubé, R., Walker, M. 2015. Bisphenol $\mathrm{A}$ and phthalate metabolite urinary concentrations: Daily and across pregnancy variability. Journal of Exposure Science and Environmental Epidemiology, 25: 231-239.

Gallart-Ayala, H., Moyano, E., Galceran, M.T. 2011. Analysis of bisphenols in soft drinks by on-line solid phase extraction fast liquid chromatographytandem mass spectrometry. Analytica Chimica Acta, 683: 227-233.

Gerona, R.R., Pan, J., Zota, A.R., Schwartz, J.M., Friesen, M., Taylor, J.A., Hunt, P.A., Woodruff, T.J. 2016. Direct measurement of bisphenol A (BPA), BPA glucuronide and BPA sulfate in a diverse and low-income population of pregnant women reveals high exposure, with potential implications for previous exposure estimates: a cross-sectional study. Environmental Health, 15: $1-14$.

Giesbrecht, G.F., Ejaredar, M., Liu, J., Thomas, J., Letourneau, N., Campbell, T., Martin, J.W., Dewey, D. 2017. Prenatal bisphenol A exposure and dysregulation of infant hypothalamic-pituitaryadrenal axis function: findings from the APrON cohort study. Environmental Health, 16: 47.

Glausiusz, J. 2014. Toxicology: the plastics puzzle. Nature, 508: 306-308.

Gong, M., Huai, Z., Song, H., Cui, L., Guo, Q., Shao, J., Gao, Y., Shi, H. 2017. Effects of maternal exposure to bisphenol AF on emotional behaviours in adolescent mice offspring. Chemosphere, 187: 140-146.

Gyllenhammar, I., Glynn, A., Jönsson, B.A.G., Lindh, C.H., Darnerud, P.O., Svensson, K., Lignell, S.
2017. Diverging temporal trends of human exposure to bisphenols and plastizisers, such as phthalates, caused by substitution of legacy EDCs. Environmental Research, 153: 48-54.

Hartmann, C., Uhl, M., Weiss, S., Scharf, S., König, J. 2016. Human bio-monitoring of bisphenol A exposure in an Austrian population. Biomonitoring, 3: 5-14.

Heffernan, A.L., Thompson, K., Eaglesham, G., Vijayasarathy, S., Mueller, J.F., Sly, P.D., Gomez, M.J. 2016. Rapid, automated online SPE-LCQTRAP-MS/MS method for the simultaneous analysis of 14 phthalate metabolites and 5 bisphenol analogues in human urine. Talanta, 151: 224-233.

Hill, C.E., Sapouckey, S.A., Suvorov, A., Vandenberg, L.N. 2017. Developmental exposures to bisphenol $\mathrm{S}$, a BPA replacement, alter estrogen-responsiveness of the female reproductive tract: A pilot study. Cogent Medicine, 4: 1317690.

Huang, R.-P., Liu, Z.-H., Yuan, S.-F., Yin, H., Dang, Z., Wu, P.-X. 2017. Worldwide human daily intakes of bisphenol A (BPA) estimated from global urinary concentration data (2000-2016) and its risk analysis. Environmental Pollution, 230: 143-152.

Ihde, E.S., Zamudio, S., Loh, J.M., Zhu, Y., Woytanowski, J., Rosen, L., Liu, M., Buckley, B. 2018. Application of a novel mass spectrometric (MS) method to examine exposure to BisphenolA and common substitutes in a maternal fetal cohort. Human and Ecological Risk Assessment, 24: 331346.

Ikhlas, S., Ahmad, M. 2020. Acute and sub-acute bisphenol-B exposures adversely affect sperm count and quality in adolescent male mice. Chemosphere, 242: 125286 .

Ishido, M., Masuo, Y., Terasaki, M., Morita, M. 2011. Rat hyperactivity by bisphenol A, but not by its derivatives, 3- hydroxybisphenol A or bisphenol A 3,4-quinone. Toxicology Letters, 206: 300305 .

Ji, K., Hong, S., Kho, Y., Choi, K. 2013. Effects of bisphenol $\mathrm{S}$ exposure on endocrine functions and reproduction of zebrafish. Environmental Science and Technology, 47: 8793-8800.

Jo, A., Kim, H., Chung, H., Chang, N. 2016. Associations 
between dietary intake and urinary bisphenol A and phthalates levels in Korean women of reproductive age. International Journal of Environmental Research and Public Health, 13: 680-693.

Kim, B., Colon, E., Chawla, S., Vandenberg, L.N., Suvorov, A. 2015. Endocrine disruptors alter social behaviours and indirectly influence social hierarchies via changes in body weight. Environmental Health, 14: 640.

Kim, E.-H., Jeon, B.-H., Kim, J., Kim, Y.-M., Han, Y., Ahn, K., Cheong, H.-K. 2017. Exposure to phthalates and bisphenol $\mathrm{A}$ are associated with atopic dermatitis symptoms in children: a time series analysis. Environmental Health, 16: 24.

Kim, K.-N., Kim, J.H., Kwon, H.-J., Hong, S.-J., Kim, B.-J., Lee, S.-Y., Hong, Y.-C., Bae, S. 2014. Bisphenol A exposure and asthma development in school-age children: A longitudinal study. PLoS ONE, 9: e111383.

Kinch, C.D., Ibhazehiebo, K., Jeong, J.H., Habibi, H.R., Kurrasch, D.M. 2015. Low-dose exposure to bisphenol A and replacement bisphenol S induces precocious hypothalamic neurogenesis in embryonic zebrafish. Proceedings of the National Academy of Sciences, 112: 1475-1480.

Konno, Y., Suzuki, H., Kudo, H., Kameyama, A., Nishikubo, T. 2004. Synthesis and properties of fluorine-containing poly(ether)s with pendant hydroxyl groups by the polyaddition of bis(oxetane)s and bisphenol AF. Polymer Journal, 36: 114-122.

Krishnapriya, K., Shobana, G., Narmadha, S., Ramesh, M., Maruthappan, V. 2017. Sublethal concentration of bisphenol A induces hematological and biochemical responses in an Indian major carp Labeo rohita. Ecohydrology and Hydrobiology, https://doi.org/10.1016/j.ecohyd.2017.06.003

Kuruto-Niwa, R., Nozawa, R., Miyakoshi, T., Shiozawa, T., Terao, Y. 2005. Estrogenic activity of alkylphenols, bisphenol $\mathrm{S}$, and their chlorinated derivatives using a GFP expression system. Environmental Toxicology and Pharmacology, 19: 121-130.

Lane, R.F., Adams, C.D., Randtke, S.J., Carter Jr, R.E. 2015a. Bisphenol diglycidyl ethers and bisphenol
A and their hydrolysis in drinking water. Water Research, 72: 331-339.

Lane, R.F., Adams, C.D., Randtke, S.J., Carter Jr, R.E. 2015b. Chlorination and chloramination of bisphenol A, bisphenol F, and bisphenol A diglycidyl ether in drinking water. Water Research, 79: 6878.

Liang, H., Xu, W., Chen, J., Shi, H., Zhu, J., Liu, X., Wang, J., Miao, M., Yuan. W. 2017. The association between exposure to environmental bisphenol A and gonadotropic hormone levels among men. PLOS ONE, 12: e0169217.

Larsson, K., Lindh, C.H., AGJönsson, B., Giovanoulis, G., Bibi, M., Bottai, M., Bergström, A., Berglund, M. 2017. Phthalates, non-phthalate plasticizers and bisphenols in Swedish preschool dust in relation to children's exposure. Environment International, 102: $114-124$

Larsson, K., Björklund, K.L., Palm, B., Wennberg, M., Kaj, L., Lindh, C.H., Jönsson, B.A.G., Berglund, M. 2014. Exposure determinants of phthalates, parabens, bisphenol A and triclosan in Swedish mothers and their children. Environment International, 73: 323-333.

Lee, S., Liu, X., Takeda, S., Choi, K. 2013. Genotoxic potentials and related mechanisms of bisphenol A and other bisphenol compounds: a comparison study employing chicken DT40 cells. Chemosphere, 93: 434-440.

Li, J., Sheng, N., Cui, R., Feng, Y., Shao, B., Guo, X., Zhang, H., Dai, J. 2016. Gestational and lactational exposure to bisphenol $\mathrm{AF}$ in maternal rats increases testosterone levels in 23-day-old male offspring. Chemosphere, 163: 552-561.

Liao, C., Kannan, K. 2013. Concentrations and profiles of bisphenol A and other bisphenol analogues in foodstuffs from the United States and their implications for human exposure. Journal of Agricultural and Food Chemistry, 61: 46554662.

Liao, C., Kannan, K. 2014a. A survey of alkylphenols, bisphenols, and triclosan in personal care products from China and the United States. Archives of Environmental Contamination and Toxicology, 67: 50-59.

Liao, C., Kannan, K. 2014b. A survey of bisphenol A 
and other bisphenol analogues in foodstuffs from nine cities in China. Food Additives and Contaminants Part A, 31: 319-329.

Liao, C., Liu, F., Moon, H.B., Yamashita, N., Yun, S., Kannan, K. 2012a. Bisphenol analogues in sediments from industrialized areas in the United States, Japan and Korea: spatial and temporal distributions. Environmental Science and Technology, 46: 11558-11565.

Liao, C., Liu, F., Alomirah, H., Loi, V.D., Mohd, M.A., Moon, H.B., Nakata, H., Kannan, K. 2012 b. Bisphenol $\mathrm{S}$ in urine from the United States and seven Asian countries: occurrence and human exposures. Environmental Science and Technology, 46: 6860-6866.

Little, A.G., Seebacher, F. 2015. Temperature determines toxicity: Bisphenol A reduces thermal tolerance in fish. Environmental Pollution, 197: 84-89.

Liu, B., Lehmler, H.-J., Sun, Y., Xu, G., Liu, Y., Zong, G., Sun, Q., Hu, F.B., Wallace, R.B., Bao, W. 2017. Bisphenol A substitutes and obesity in US adults: analysis of a population-based, cross-sectional study. Lancet Planet Health, 1: e114-122.

Mathew, M., Sreedhanya, S., Manoj, P., Aravindakumar, C.T., Aravind, U.K. 2014. Exploring the interaction of Bisphenol-S with serum albumins: A better or worse alternative for Bisphenol A. The Journal of Physical Chemistry B, 118: 3832-3843.

Molina-Molina, J.M., Amaya, E., Grimaldi, M., Saenz, J.M., Real, M., Fernandez, M.F., Balaguer, P., Olea, N. 2013. In vitro study on the agonistic and antagonistic activities of bisphenol-S and other bisphenol-A congeners and derivatives via nuclear receptors. Toxicology and Applied Pharmacology, 272: 127-136.

Moral, L.I.D., Corre, L.L., Poirier, H., Niot, I., Truntzer, T., Merlin, J.-F., Rouimi, P., Besnard, P., Rahmani, R., Chagnon, M.C. 2016. Obesogen effects after perinatal exposure of $4,4^{\prime}$ sulfonyldiphenol (bisphenol S) in C57BL/6 mice. Toxicology, 357358: $11-20$.

Naderi, M., Wong, M.Y., Gholami, F. 2014. Developmental exposure of zebrafish (Danio rerio) to bisphenol-S impairs subsequent reproduction potential and hormonal balance in adults. Aquatic Toxicology, 148: 195-203.
Ohtani, N., Iwano, H., Suda, K., Tsuji, E., Tanemura, K., Inoue, H., Yokota, H. 2017. Adverse effects of maternal exposure to bisphenol $\mathrm{F}$ on the anxietyand depression like behaviour of offspring. Journal of Veterinary Medical Science, 79: 432-439.

Owens, J.W., Ashby, J. 2002. Critical review and evaluation of the uterotrophic bioassay for the identification of possible estrogen agonists and antagonists: in support of the validation of the OECD uterotrophic protocols for the laboratory rodent. Critical Reviews in Toxicology, 32: 445 520.

Pal, S., Sarkar, K., Nath, P.P., Mondal, M., Khatun, A., Paul, G. 2017. Bisphenol S impairs blood functions and induces cardiovascular risks in rats. Toxicology Reports, 4: 560-565.

Pelch, K., Wignall, J.A., Goldstone, A.E., Ross, P.K., Blain, R.B., Shapiro, A.J., Holmgren, S.D., Hsieh, J.-H., Svoboda, D., Auerbach, S.S., Parham, F.M., Masten, S.A., Walker, V., Rooney, A., Thayer, K.A. 2019. A scoping review of the health and toxicological activity of bisphenol A (BPA) structural analogues and functional alternatives. Toxicology, 424: 152235.

Pell, T., Eliot, M., Chen, A., Lanphear, B.P., Yolton, K., Sathyanarayana, S., Braun, J.M. 2017. Parental concern about environmental chemical exposures and children's urinary concentrations of phthalates and phenols. The Journal of Pediatrics, 186: 138144.

Peng, F., Ji, W., Zhu, F., Peng, D., Yang, M., Liu, R., $\mathrm{Pu}$, Y., Yin, L. 2016. A study on phthalate metabolites, bisphenol A and nonylphenol in the urine of Chinese women with unexplained recurrent spontaneous abortion. Environmental Research, 150: $622-628$.

Peretz, J., Vrooman, L., Ricke, W.A., Hunt, P.A., Ehrlich, S., Hauser, R., Padmanabhan, V., Taylor, H.S., Swan, S.H., VandeVoort, C.A., Flaws, J.A. 2014. Bisphenol A and reproductive health: Update of experimental and human evidence, 2007 2013. Environmental Health Perspectives, 122: 775-786.

Peyre, L., Rouimi, P., de Sousa, G., Héliès-Toussaint, C., Carré, B., Barcellini, S., Chagnon, M.-C., Rahmani, R. 2014. Comparative study of bisphenol 
A and its analogue bisphenol $\mathrm{S}$ on human hepatic cells: A focus on their potential involvement in nonalcoholic fatty liver disease. Food and Chemical Toxicology, 70: 9-18.

Porras, S.P., Heinala, M., Santonen, T. 2014. Bisphenol A exposure via thermal paper receipts. Toxicology Letters, 230: 413-420.

Qiu, W., Zhao, Y., Yang, M., Farajzadeh, M., Pan, C., Wayne, N.L. 2016. Actions of bisphenol A and bisphenol $\mathrm{S}$ on the reproductive neuroendocrine system during early development in zebrafish. Endocrinology, 157: 636-647.

Qiu, W., Zhao, Y., Yang, M., Farajzadeh, M., Pan, C., Wayne, N.L. 2015. Actions of bisphenol A and bisphenol $\mathrm{S}$ on the reproductive neuroendocrine system during early development in zebrafish. Endocrinology, 157: 636-647.

Rashidi, B.H., Amanlou, M., Lak, T.B., Ghazizadeh, M., Eslami, B. 2017. A case-control study of bisphenol A and endometrioma among subgroup of Iranian women. Journal of Research in Medical Sciences, 22: 7.

Rocha, B.A., da Costa, B.R.B., de Albuquerque, N.C.P., de Oliveira, A.R.M., Souza, J.M.O., Al-Tameemi, M., Campiglia, A.D., Jr., F.B. 2016. A fast method for bisphenol A and six analogues (S, F, Z, P, AF, AP) determination in urine samples based on dispersive liquid-liquid microextraction and liquid chromatography-tandem mass spectrometry. Talanta, 154: 511-519.

Rochester, J.R., Bolden, A.L. 2015. Bisphenol S and F: A systematic review and comparison of the hormonal activity of bisphenol A substitutes. Environmental Health Perspectives, 123: 643-650.

Rosenfeld, C.S. 2017. Neuro-endocrine disruption in animal models due to exposure to bisphenol A analogues. Frontiers in Neuro-endocrinology, 47: 123-133.

Rosenmai, A.K., Dybdahl, M., Pedersen, M., van VugtLussenburg, B.M.A., Wedebye, E.B., Taxvig, C., Vinggaard, A.M. 2014. Are structural analogues to Bisphenol A safe alternatives? Toxicological Sciences, 139: 35-47.

Rubin, B.S., Paranjpe, M., DaFonte, T., Schaeberle, C., Soto, A.M., Obin, M., Greenberg, A.S. 2017. Perinatal BPA exposure alters body weight and composition in a dose specific and sex specific manner: The addition of peripubertal exposure exacerbates adverse effects in female mice. Reproductive Toxicology, 68: 130-144.

Russo, G., Barbato, F., Grumetto, L. 2017. Monitoring of bisphenol A and bisphenol S in thermal paper receipts from the Italian market and estimated transdermal human intake: A pilot study. Science of The Total Environment, 599-600: 68-75.

Salvesen, G.S., Walsh, C.M. 2014. Functions of caspase 8: the identified and the mysterious. Seminars in Immunology, 26: 246-252.

Santamaria, C., Durando, M., Munoz de Toro, M., Luque, E.H., Rodriguez, H.A. 2016. Ovarian dysfunction in adult female rat offspring born to mothers perinatally exposed to low doses of bisphenol A. The Journal of Steroid Biochemistry and Molecular Biology, 158: 220-230.

Shi, J., Jiao, Z., Zheng, S., Li, M., Zhang, J., Feng, Y., Yin, J., Shao, B. 2015. Long-term effects of Bisphenol AF (BPAF) on hormonal balance and genes of hypothalamus-pituitary-gonad axis and liver of zebrafish (Danio rerio), and the impact on offspring. Chemosphere, 128: 252-257.

Shi, M., Sekulovski, N., MacLean, J.A., Hayashi, K. 2017. Effects of bisphenol A analogues on reproductive functions in mice. Reproductive Toxicology, 73: 280-291.

Singh, R.P., Shafeeque, C.M., Sharma, S.K., Singh, R., Kannan, M., Sastry, K.V.H., Raghunandanan, S., Mohan, J., Azeez, P.A. 2016. Effects of bisphenolA on male reproductive success in adult Kadaknath chicken. Ecotoxicology and Environmental Safety, 128: 61-66.

Smarr, M.M., Grantz, K.L., Sundaram, R., Maisog, J.M., Kannan, K., Louis, G.M.B. 2015. Parental urinary biomarkers of preconception exposure to bisphenol A and phthalates in relation to birth outcomes. Environmental Health, 14: 73.

Tang, T., Yang, Y., Chen, Y., Tang, W., Wang, F., Diao, X. 2015. Thyroid disruption in zebrafish larvae by short-term exposure to bisphenol AF. International Journal of Environmental Research and Public Health, 12: 13069-13084.

Teng, C., Goodwin, B., Shockley, K., Xia, M., Huang, R., Norris, J., Merrick, B.A., Jetten, A.M., Austin, 
C.P., Tice, R.R. 2013. Bisphenol A affects androgen receptor function via multiple mechanisms. Chemico-Biological Interactions, 203: 556-564.

Ullah, H., Jahan, S., Ain, Q.U., Shaheen, G., Ahsan, N. 2016. Effect of bisphenol $\mathrm{S}$ exposure on male reproductive system of rats: A histological and biochemical study. Chemosphere, 152: 383-391.

Vandenberg, L.N., Ehrlich, S., Belcher, S.M., BenJonathan, N., Dolinoy, D.C., Hugo, E.R., Hunt, P.A., Newbold, R., Rubin, B.S., Saili, K., Soto, A.M., Wang, H.S., vom Saal F.S. 2013. Low dose effects of bisphenol A: an integrated review of in vitro, laboratory animal and epidemiology studies. Endocrine Disruptors, 1: e25078.

Vandenberg, L.N., Luthi, D., Quinerly, D. 2017. Plastic bodies in a plastic world: Multi disciplinary approaches to study endocrine disrupting chemicals. Journal of Cleaner Production, 140: 373-385.

Vinas, R., Watson, C.S. 2013a. Bisphenol S disrupts estradiol-induced nongenomic signaling in a rat pituitary cell line: effects on cell functions. Environmental Health Perspectives, 121: 352358.

Vinas, R., Watson, C.S. 2013b. Mixtures of xenoestrogens disrupt estradiol-induced non genomic signaling and downstream functions in pituitary cells. Environmental Health, 12: 26.

Wang, W., Abualnaja, K.O., Asimakopoulos, A.G., Covaci, A., Gevao, B., Johnson-Restrepo, B., Kumosani, T.A., Malarvannan, G., Minh, T.B., Moon, H.-B., Nakata, H., Sinha, R.K., Kannan, K. 2015. A comparative assessment of human exposure to tetra bromobisphenol A and eight bisphenols including bisphenol A via indoor dust ingestion in twelve countries. Environment International, 83: 183-191.

Wang, W., Wu, F.Y., Huang, M.J., Kang, Y., Cheung, K.C., Wong, M.H. 2013. Size fraction effect on phthalate esters accumulation, bio-accessibility and in vitro cytotoxicity of indoor/outdoor dust and risk assessment of human exposure. Journal of Hazardous Materials, 261: 753-762.

Xue, J., Wu, Q., Sakthivel, S., Pavithran, P.V., Vasukutty, J.R., Kannan, K. 2015. Urinary levels of endocrinedisrupting chemicals, including bisphenols, bisphenol A diglycidyl ethers, benzophenones, parabens and triclosan in obese and non-obese Indian children. Environmental Research, 137: 120-128.

Yamamoto, J., Minatoya, M., Sasaki, S., Araki, A., Miyashita, C., Matsumura, T., Kishi, R. 2016. Quantifying bisphenol A in maternal and cord whole blood using isotope dilution liquid chromatography/tandem mass spectrometry and maternal characteristics associated with bisphenol A. Chemosphere, 164: 25-31.

Yamasaki, K., Noda, S., Imatanaka, N., Yakabe, Y. 2004. Comparative study of the uterotrophic potency of 14 chemicals in a uterotrophic assay and their receptorbinding affinity. Toxicology Letters, 146: 111-120.

Yang, Y., Guan, J., Yin, J., Shao, B., Li, H. 2014a. Urinary levels of bisphenol analogues in residents living near a manufacturing plant in south China. Chemosphere, 112: 481-486.

Yang, Y., Lu, L., Zhang, J., Yang, Y., Wu, Y., Shao, B. 2014b. Simultaneous determination of seven bisphenols in environmental water and solid samples by liquid chromatography electrospray tandem mass spectrometry. Journal of Chromatography A, 1328: $26-34$.

Ye, X., Pierik, F.H., Angerer, J., Meltzer, H.M., Jaddoe, V.W.V., Tiemeier, H., Hoppin, J.A., Longnecker, M.P. 2009. Levels of metabolites of organophosphate pesticides, phthalates and bisphenol A in pooled urine specimens from pregnant women participating in the Norwegian Mother and Child Cohort Study (MoBa). International Journal of Hygiene and Environmental Health, 212: 481491.

Ye, X., Pierik, F.H., Hauser, R., Duty, S., Angerer, J., Park, M.M., Burdorf, A., Hofman, A., Jaddoe, V.W.V., Mackenbach, J.P., Steegers, E.A.P., Tiemeier, H., Longnecker, M.P. 2008. Urinary metabolite concentrations of organophosphorous pesticides, bisphenol A, and phthalates among pregnant women in Rotterdam, the Netherlands: The Generation R Study. Environmental Research, 108: 260-267.

Ye, X., Wong, L.Y., Kramer, J., Zhou, X., Jia, T., Calafat, A.M. 2015. Urinary concentrations of bisphenol A and three other bisphenols in convenience samples 
of U.S. adults during 2000-2014. Environmental Science \& Technology, 49: 11834-11839.

Žalmanova, T., Hoškova, K., Nevoral, J., Prokešova, Š., Zamostna, K., Kott, T., Petr, J. 2016. Bisphenol $\mathrm{S}$ instead of bisphenol A: a story of reproductive disruption by regretable substitution-a review. Czech Journal of Animal Science, 61: 433-449.

Zhang, J., Zhang, T., Guan, T., Ruan, P., Ren, D., Dai, W., Yu, H., Li, T. 2017. Spectroscopic and molecular modeling approaches to investigate the interaction of bisphenol A, bisphenol $\mathrm{F}$ and their diglycidyl ethers with PPAR $\alpha$. Chemosphere, 180: 253-258.

Zhao, F., Jiang, G., Wei, P., Wang, H., Ru, S. 2018. Bisphenol S exposure impairs glucose homeostasis in male zebrafish (Danio rerio). Ecotoxicology and Environmental Safety, 147: 794-802.
Zhou, X., Kramer, J.P., Calafat, A.M., Ye, X. 2014. Automated on-line column-switching high performance liquid chromatography isotope dilution tandem mass spectrometry method for the quantification of bisphenol A, bisphenol F, bisphenol $\mathrm{S}$, and 11 other phenols in urine. Journal of Chromatography B, 944: 152-156.

Zhu, X., Wu, G., Xing, Y., Wang, C., Yuan, X., Li, B. 2020. Evaluation of single and combined toxicity of bisphenol A and its analogues using a highlysensitive micro-biosensor. Journal of Hazardous Materials, 381: 1-9.

Zoller, O., Brüschweiler, B.J., Magnin, R., Reinhard, H., Rhyn, P., Rupp, H., Zeltner, S., Felleisen, R. 2016. Natural occurrence of bisphenol $\mathrm{F}$ in mustard. Food Additives \& Contaminants: Part A, 33: 137-146. 